Research Article

\title{
Evaluation of antidepressant activity of ondansetron alone and in combination with fluoxetine-an experimental study
}

\author{
Sonal M. Parekar*, Shrikant C. Dharmadhikari, Jugalkishore B. Jaju, Ganesh R. Pawar, \\ Rajvardhan Solunke
}

\begin{abstract}
Department of Pharmacology, Government Medical College, Latur, Maharashtra, India 413512
\end{abstract}

Received: 29 November 2015 Accepted: 18 December 2015

*Correspondence to:

Dr. Sonal M. Parekar,

Email: drsonal.vm@gmail.com

Copyright: (C) the author(s), publisher and licensee Medip Academy. This is an open-access article distributed under the terms of the Creative Commons Attribution Non-Commercial License, which permits unrestricted non-commercial use, distribution, and reproduction in any medium, provided the original work is properly cited.

\begin{abstract}
Background: Direct antagonism at $5 \mathrm{HT}_{3}$ receptor site may be associated with antidepressant activity as conventional antidepressants also possess affinity for central $5 \mathrm{HT}_{3}$ binding site. So in this study, an effort is made to investigate the antidepressant effect of ondansetron (OND), a selective $5 \mathrm{HT}_{3}$ antagonist, alone and in combination with fluoxetine (FLX).

Methods: Acute and chronic models of Forced swimming test (FST), tail suspension test (TST), open field test (OFT) and mice brain serotonin estimation by UV spectrophotometry were applied for the evaluation of antidepressant activity.

Results: In FST and TST (acute and chronic models), ondansetron showed statistically significant antidepressant activity $(\mathrm{p}<0.05)$ as compared to control. The combination groups (OND $0.25 \mathrm{mg} / \mathrm{kg}+$ FLX 5mg/kg \& OND $0.5 \mathrm{mg} / \mathrm{kg}+$ FLX $5 \mathrm{mg} / \mathrm{kg}$ ) showed statistically significant antidepressant activity $(\mathrm{p}<0.05)$ as compared to fluoxetine $(5 \mathrm{mg} / \mathrm{kg})$ and ondansetron $(0.25 \mathrm{mg} / \mathrm{kg}$ and 0.5 $\mathrm{mg} / \mathrm{kg}$ ) in FST and TST (acute and chronic models). Open field test in chronic study showed ondansetron $(0.25 \mathrm{mg} / \mathrm{kg}$ and $0.5 \mathrm{mg} / \mathrm{kg})$ increases number of central squares crossed as compared to control which is statistically significant $(\mathrm{p}<0.05)$. The combination group (OND $0.25 \mathrm{mg} / \mathrm{kg}+$ FLX $5 \mathrm{mg} / \mathrm{kg}$ ) showed significantly increased $(\mathrm{p}<0.05)$ number of central squares crossed as compared to fluoxetine $(5 \mathrm{mg} / \mathrm{kg}$ ). The combination group (OND $0.5 \mathrm{mg} / \mathrm{kg}+$ FLX 5 $\mathrm{mg} / \mathrm{kg}$ ) showed significantly increased $(\mathrm{p}<0.05)$ brain serotonin compared to control, ondansetron $(0.25 \mathrm{mg} / \mathrm{kg}$ and $0.5 \mathrm{mg} / \mathrm{kg})$ and fluoxetine $(5 \mathrm{mg} / \mathrm{kg})$.

Conclusions: Our study concludes that ondansetron alone and in combination with fluoxetine possesses significant antidepressant activity in animal models of depression.
\end{abstract}

Keywords: Antidepressant, Ondansetron, Fluoxetine, Brain serotonin

\section{INTRODUCTION}

Depression is a mental disorder, defined as depressed mood on daily basis for a minimum duration of 2 weeks. According to the world health report approximately 450 million people suffer from mental or behavioural disorder with loss of 850000 lives every year globally. ${ }^{1}$ In that depression is the most prevalent mental disorder. ${ }^{2}$ In India the prevalence of depression is 31.2 per 1000 population. $^{3}$

Depression can be treated by drug therapy, psychotherapy, electroconvulsive therapy and light therapy. Drugs like monoamine oxidase inhibitors, tricyclic antidepressants, selective serotonin reuptake inhibitors and atypical antidepressants are successfully used in the treatment of depression. Inspite availability of antidepressant drugs, depression continues to be a major problem. ${ }^{4}$ Hence there is need to develop newer antidepressants.

The interaction of genetic and environmental risk factors leads to depression. The main symptoms of depression are due to functional deficiency in the level of monoaminergic neurotransmitters like norepinephrine (NE), 5-hydroxytryptamine (5HT) and dopamine (DA) in the brain. ${ }^{5}$ The drugs that increase the level of these neurotransmitters in the CNS show antidepressant activity. Direct antagonism at $5 \mathrm{HT}_{3}$ receptor site may be associated with antidepressant activity as conventional antidepressants also possess affinity for central $5 \mathrm{HT}_{3}$ binding site. ${ }^{6}$ Commercially available antidepressants like fluoxetine showed antidepressant activity by blocking 
$5 \mathrm{HT}_{3}$ receptors. $^{7}$ As Greenshow suggested possible involvement of $5 \mathrm{HT}_{3}$ receptors in depression. ${ }^{8}$

Ondansetron is a selective $5 \mathrm{HT}_{3}$ receptor antagonist used as an antiemetic which showed potent antidepressant like effect and was evaluated for its efficacy in depression in few studies. ${ }^{9}$ So in this study, an effort is made to investigate the antidepressant effect of ondansetron alone, in comparison and combination with fluoxetine.

\section{METHODS}

This study was performed at pharmacology department Govt. medical college Latur. The study protocol was approved by institutional animal ethics committee and was carried out in accordance with CPCSEA guidelines.

\section{Chemicals and solutions}

FLX was purchased from Palam Pharma pvt. limited, Ahmedabad. OND was purchased from research lab fine chemical Industries, Mumbai. Distilled water was used as solvent for both drugs. Methanol, ethanol, HCL, Ehrlich reagent purchased from Hi media pvt. limited, Mumbai.

\section{Experimental animals}

Healthy swiss albino mice of either sex weighing 30-35 gm were used in experiment. Animals were acclimatized to the laboratory conditions for the period of seven days and fed with standard diet and water ad libitum under strict hygienic conditions; both were withdrawn on the day of experiment. They were maintained under standard 12 hours light and dark cycle.

\section{Study design}

After 7 day period of acclimatization, the animals were divided into 6 groups, 6 animals in each group. For acute study single and for chronic study 14 days injections were given intraperitoneally. Group I - normal healthy albino mice (distilled water $5 \mathrm{ml} / \mathrm{kg}$ ), group II ondansetron $(0.25 \mathrm{mg} / \mathrm{kg})^{10}$, group III - ondansetron (5 $\mathrm{mg} / \mathrm{kg})^{10}$, group IV - fluoxetine $(5 \mathrm{mg} / \mathrm{kg})^{10}$, group $\mathrm{V}$ ondansetron $(0.25 \mathrm{mg} / \mathrm{kg})+$ fluoxetine $(5 \mathrm{mg} / \mathrm{kg})$, group VI - ondansetron $(0.5 \mathrm{mg} / \mathrm{kg})+$ fluoxetine $(5 \mathrm{mg} / \mathrm{kg})$. Same animals were used for all the tests. All the tests of each group were performed on same day after $1 \mathrm{hr}$. of administration of drugs.

\section{Equipments}

Forced swimming cylinders $(25 \mathrm{~cm} \times 10 \mathrm{~cm})$, Tail suspension apparatus, open field apparatus, UV spectrophotometer 1800 (Schimatzu).

\section{Methods}

Animals were allowed to acclimatize to the experimental room for 1-2 hrs. before the behavioural procedure.

\section{Forced swimming test ${ }^{6,7,11}$}

This method is based on the principle that a mouse forced to swim in a cylindrical vessel will stop struggling and remain afloat passively, which is termed as immobility. The test was performed in acute and chronic model along with habituation session before acute test. In habituation session mice were forced to swim in glass cylinder for 15 min on the pre-test day i.e. 24 hrs. before commencing the test. Mice were wiped with dry cloth and allowed to dry before returning to their home cages. Water was changed for each animal.

In acute study single dose of drug was given and $1 \mathrm{hr}$. after drug administration test was performed. Mice were individually placed in glass cylinder $(30 \mathrm{~cm}$ height and $22.5 \mathrm{~cm}$ diameter) filled with water at a height of $15 \mathrm{~cm}$. At this height animals were not able to support themselves by bottom and sidewalls of the chamber. Their behaviour was observed for 6 mins by video recording camera. The immobility period is recorded for 6 mins which is characterized by only small movements necessary to keep his head above the level of water. Immobility period was counted with the time sampling method. In chronic study, drugs were administered for 14 days and on $14^{\text {th }}$ day, test was performed after $1 \mathrm{hr}$. of drug administration same as that of acute study.

\section{Tail suspension test $t^{7,11,12}$}

In this test immobility was induced by suspending the mice by the tail. The method is based on the principle that a mouse suspended by tail above a fixed height of $58 \mathrm{~cm}$ from the ground shows alternate periods of agitation and immobility. In acute study single dose of drug was given and $1 \mathrm{hr}$. after drug administration test was performed. The test was conducted in dim lighted room. Mice were individually suspended to the tail suspension apparatus $58 \mathrm{~cm}$ above the ground by the adhesive tape placed approximately $1 \mathrm{~cm}$ from tip of the tail. Each animal under study was visually and acoustically isolated from other animals during test. Animal was considered immobile when it didn't show any body movement, hung passively and completely motionless. The activity of mice was recorded using a video camera for the period of 6 mins. Immobility period was counted with time sampling method. In chronic study, drugs were administered for 14 days and on $14^{\text {th }}$ day, test was performed after $1 \mathrm{hr}$. of drug administration same as that of acute study.

\section{Open field test ${ }^{12}$}

This test utilizes behavioural changes in rodents exposed to novel environment and is used to confirm that the observed antidepressant effect is not due to stimulation of general motor activity. The open field test was carried out on dark grey floor subdivided into 16 equal parts in a wooden box $(100 \mathrm{~cm} \times 100 \mathrm{~cm} \times 30 \mathrm{~cm})$. In acute study, single dose of drug was given to the animals and $1 \mathrm{hr}$. 
later the animals were individually placed in the corner square of the open field apparatus. The following parameters were observed for 5 mins. Activity in the centre (number of central squares crossed), activity in the periphery (number of peripheral squares crossed in the periphery), rearing (no. of times the animal stands on the rear paws).

Floor of apparatus was cleaned with spirit after each animal. In chronic study, drugs were administered for 14 days. On $14^{\text {th }}$ day test was performed $1 \mathrm{hr}$. after administration of drug same as that of acute study.

\section{Mice brain serotonin estimation ${ }^{10}$}

First calibration curve of serotonin is plotted and mice brain serotonin concentration is compared with the curve.

\section{Procedure for calibration curve}

Working standard solution is prepared by dilution of stock standard solution with methanol. An aliquot of working stdandard solution $(2 \mathrm{ml})$ is transferred respectively into seven $10 \mathrm{ml}$ volumetric flasks; $5 \mathrm{ml}$ Ehrlich's reagent is added. The solution is heated at $50^{\circ} \mathrm{C}$, cooled diluted to the mark with $0.1 \mathrm{~mol} / \mathrm{lit} \mathrm{HCl}$ solution. After reshaking to homogeneity, the mixtures were measured in a $1 \mathrm{~cm}$ cell at $275 \mathrm{~nm}$ for absorbance. ${ }^{12}$ The reagent blank is prepared in the same way as the reaction mixture except for working standard solution being replaced with equal volume of $0.1 \mathrm{~mol} / \mathrm{lit} \mathrm{HCl}$ was used as reference.

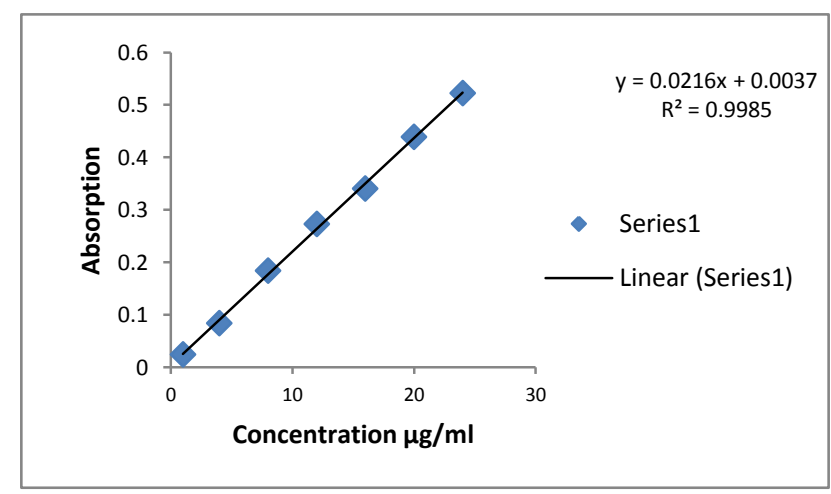

Figure 1: Calibration curve.

\section{Sample analysis}

The brain sample was washed with methanol. The sample is then homogenized in cooling centrifuge at $4^{\circ} \mathrm{C}$ at 2700 $\mathrm{g}$ for $10 \mathrm{~min}$. The supernatant was used as final sample for spectrophotometric analysis. The samples of desired amounts were respectively diluted to the mark with methanol in $10 \mathrm{ml}$ volumetric flasks. $2 \mathrm{ml}$ of the sample solution was transferred to the $50 \mathrm{ml}$ volumetric flask, diluted to the mark with methanol. $2 \mathrm{ml}$ of the aliquot of the diluted sample solution was reacted with Ehrlich's reagent and finally the reaction mixture was measured for absorbance. The relevant serotonin derivatives conc. was calculated using the calibration curve.

\section{Statistical analysis}

Data was collected and expressed as mean \pm SEM. The results of data were analyzed by one way ANOVA followed by Tukeys multiple comparison test ("Graph pad prism version 5.00 for windows, graph pad software, San Diego California USA,www.graphpad.com.”). p value $<0.05$ was taken as statistically significant.

\section{RESULTS}

In acute study of forced swimming test, ondansetron $(0.5$ $\mathrm{mg} / \mathrm{kg}$ ), fluoxetine and both combination groups show significant decrease in immobility period as compared to control. Fluoxetine and both combination groups shows significant decrease in immobility period compared to ondansetron. Combination of ondansetron and fluoxetine shows significant decrease in immobility period compared to fluoxetine.

In chronic study of forced swimming test, all the groups show significant decrease in immobility period as compared to control. Fluoxetine and both combination groups shows significant decrease in immobility period compared to ondansetron. Combination of ondansetron and fluoxetine shows significant decrease in immobility period compared to fluoxetine.

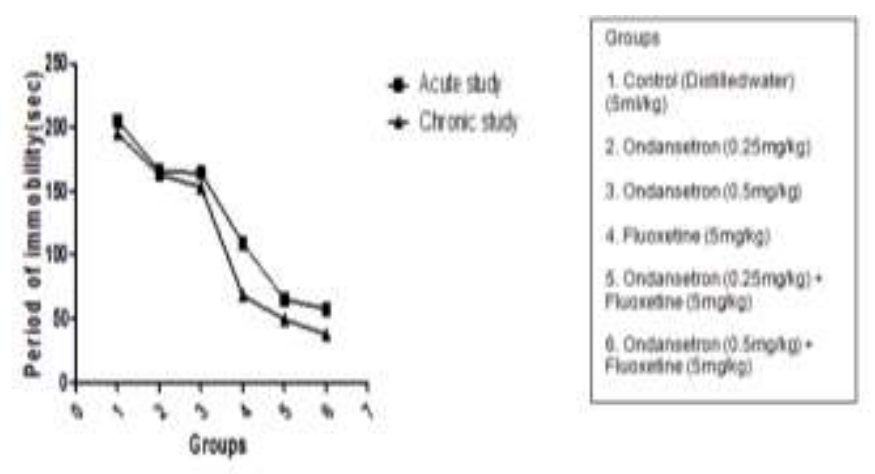

Figure 2: FST (acute and chronic study). 
Table 1: FST (Acute and chronic study).

\begin{tabular}{|lllll|}
\hline Groups & Drugs & Dose & \multicolumn{2}{l|}{ Period of immobility(sec.) } \\
\hline Group I & Control(d. w) & $5 \mathrm{ml} / \mathrm{kg}$ & Acute study & Chronic study \\
\hline Group II & OND & $0.25 \mathrm{mg} / \mathrm{kg}$ & $205 \pm 16.33$ & $195 \pm 1.82$ \\
\hline Group III & OND & $0.5 \mathrm{mg} / \mathrm{kg}$ & $165.8 \pm 7.89$ & $163.3 \pm 6.28^{\mathrm{a}}$ \\
\hline Group IV & FLX & $5 \mathrm{mg} / \mathrm{kg}$ & $164.2 \pm 7.68^{\mathrm{a}}$ & $153.3 \pm 2.10^{\mathrm{a}}$ \\
\hline Group V & ODN+FLX & $0.25+5 \mathrm{mg} / \mathrm{kg}$ & $109.2 \pm 4.90^{\mathrm{a}, \mathrm{b}, \mathrm{c}}$ & $68.33 \pm 2.78^{\mathrm{a}, \mathrm{b}, \mathrm{c}}$ \\
\hline Group VI & ODN+FLX & $0.5+5 \mathrm{mg} / \mathrm{kg}$ & $65 \pm 7.30^{\mathrm{a}, \mathrm{b}, \mathrm{c}, \mathrm{d}}$ & $49.17 \pm 2.38^{\mathrm{a}, \mathrm{b}, \mathrm{c}, \mathrm{d}}$ \\
\hline
\end{tabular}

Statistical analysis of data was carried out by one way ANOVA followed by Tukey's test. Values expressed as Mean \pm SEM [Standard error of mean]; $\mathrm{n}=6$ in each group, $\mathrm{df}=5,30$; ap $<0.05$ when compared to control, $\mathrm{bp}<0.05$ when compared to ondansetron alone $(0.25$ $\mathrm{mg} / \mathrm{kg}), \mathrm{cp}<0.05$ when compared to ondansetron alone $(0.5 \mathrm{mg} / \mathrm{kg}), \mathrm{dp}<0.05$ when compared to fluoxetine alone.

Table 2: TST (Acute and chronic study).

\begin{tabular}{|lllll|}
\hline & Drugs & Dose & \multicolumn{2}{l|}{ Period of immobility (sec.) } \\
\hline Groups I & Control(d. w) & $5 \mathrm{ml} / \mathrm{kg}$ & Acute study & Chronic study \\
\hline Group II & OND & $0.25 \mathrm{mg} / \mathrm{kg}$ & $190 \pm 6.19$ & $145 \pm 4.28$ \\
\hline Group III & OND & $0.5 \mathrm{mg} / \mathrm{kg}$ & $144.5 \pm 9.01$ & $124.2 \pm 1.53^{\mathrm{a}}$ \\
\hline Group IV & FLX & $5 \mathrm{mg} / \mathrm{kg}$ & $96.67 \pm 8.08^{\mathrm{a}, \mathrm{b}, \mathrm{c}}$ & $78.33 \pm 1.66^{\mathrm{a}, \mathrm{b}, \mathrm{c}}$ \\
\hline Group V & ODN+FLX & $0.25+5 \mathrm{mg} / \mathrm{kg}$ & $101.7 \pm 9.18^{\mathrm{a}, \mathrm{b}, \mathrm{c}}$ & $90.83 \pm 2.38^{\mathrm{a}, \mathrm{b}, \mathrm{c}, \mathrm{d}}$ \\
\hline Group VI & ODN+FLX & $0.5+5 \mathrm{mg} / \mathrm{kg}$ & $110.8 \pm 5.38^{\mathrm{a}, \mathrm{b}, \mathrm{c}}$ & $87.50 \pm 2.50^{\mathrm{a}, \mathrm{b}, \mathrm{c}}$ \\
\hline
\end{tabular}

Statistical analysis of data was carried out by one way ANOVA followed by Tukey's test. Values expressed as Mean \pm SEM [Standard error of mean]; $\mathrm{n}=6$ in each group, $\mathrm{df}=5,30 ; \mathrm{ap}<0.05$ when compared to control, $\mathrm{bp}<0.05$ when compared to ondansetron alone $(0.25$ $\mathrm{mg} / \mathrm{kg}), \mathrm{cp}<0.05$ when compared to Ondansetron alone $(0.5 \mathrm{mg} / \mathrm{kg}), \mathrm{dp}<0.05$ when compared to fluoxetine alone.

Table 3: Open field test (Acute study)

\begin{tabular}{|llllll|} 
Group & Drugs & Doses & $\begin{array}{l}\text { No. of central } \\
\text { squares crossed }\end{array}$ & $\begin{array}{l}\text { No. of peripheral } \\
\text { squares crossed }\end{array}$ & $\begin{array}{l}\text { Total no. of } \\
\text { rearing }\end{array}$ \\
\hline Group I & Control(d. w) & $5 \mathrm{ml} / \mathrm{kg}$ & $11.33 \pm 1.68$ & $82.67 \pm 3.21$ & $14.67 \pm 1.70$ \\
\hline Group II & OND & $0.25 \mathrm{mg} / \mathrm{kg}$ & $15.17 \pm 3.53$ & $89.50 \pm 5.73$ & $24.67 \pm 2.91$ \\
\hline Group III & OND & $0.5 \mathrm{mg} / \mathrm{kg}$ & $17.50 \pm 2.21$ & $109.3 \pm 10.95$ & $26 \pm 2.76$ \\
\hline Group IV & FLX & $5 \mathrm{mg} / \mathrm{kg}$ & $16.33 \pm 4.20$ & $90.33 \pm 8.64$ & $29.83 \pm 2.78^{\mathrm{a}}$ \\
\hline Group V & ODN+FLX & $0.25+5 \mathrm{mg} / \mathrm{kg}$ & $8 \pm 3.21$ & $78.67 \pm 9.97$ & $14.83 \pm 2.83^{\mathrm{d}}$ \\
\hline Group VI & ODN+FLX & $0.5+5 \mathrm{mg} / \mathrm{kg}$ & $7.83 \pm 2.82$ & $83.17 \pm 5.29$ & $14.67 \pm 3.56^{\mathrm{d}}$ \\
\hline
\end{tabular}

Statistical analysis of data was carried out by one way ANOVA followed by Tukey's test. Values expressed as Mean \pm SEM [Standard error of mean]; $\mathrm{n}=6$ in each group, $\mathrm{df}=5,30$; ap $<0.05$ when compared to control, $\mathrm{dp}<0.05$ when compared to fluoxetine alone.

Table 4: Open field test (chronic study 14 days).

\begin{tabular}{|llllll|} 
Group & Drugs & Doses & $\begin{array}{l}\text { No. of central } \\
\text { squares crossed }\end{array}$ & $\begin{array}{l}\text { No. of peripheral } \\
\text { squares crossed }\end{array}$ & $\begin{array}{l}\text { Total no. of } \\
\text { rearing }\end{array}$ \\
\hline Group I & Control(d. w) & $5 \mathrm{ml} / \mathrm{kg}$ & $9.66 \pm 0.21$ & $72 \pm 3.70$ & $18.67 \pm 1.20$ \\
\hline Group II & OND & $0.25 \mathrm{mg} / \mathrm{kg}$ & $14.50 \pm 0.99^{\mathrm{a}}$ & $80 \pm 7.96$ & $21.33 \pm 1.17$ \\
\hline Group III & OND & $0.5 \mathrm{mg} / \mathrm{kg}$ & $13 \pm 0.89^{\mathrm{a}}$ & $82 \pm 2.44$ & $23.17 \pm 0.98^{\mathrm{a}}$ \\
\hline Group IV & FLX & $5 \mathrm{mg} / \mathrm{kg}$ & $5.16 \pm 0.30^{\mathrm{a}, \mathrm{b}, \mathrm{c}}$ & $65.33 \pm 3.72$ & $14.83 \pm 1.10^{\mathrm{b}, \mathrm{c}}$ \\
\hline Group V & ODN+FLX & $0.25+5 \mathrm{mg} / \mathrm{kg}$ & $9 \pm 1.12^{\mathrm{b}, \mathrm{c}, \mathrm{d}}$ & $77.50 \pm 3.47$ & $14.50 \pm 0.80^{\mathrm{b}, \mathrm{c}}$ \\
\hline Group VI & ODN+FLX & $0.5+5 \mathrm{mg} / \mathrm{kg}$ & $6.66 \pm 0.33^{\mathrm{b}, \mathrm{c}}$ & $97.83 \pm 1.93^{\mathrm{a}, \mathrm{d}}$ & $14.67 \pm 0.76^{\mathrm{b}, \mathrm{c}}$ \\
\hline
\end{tabular}

Statistical analysis of data was carried out by one way ANOVA followed by Tukey's test. Values expressed as Mean \pm SEM [Standard error of mean]; $\mathrm{n}=6$ in each group, $\mathrm{df}=5,30 ; \mathrm{ap}<0.05$ when compared to control, $\mathrm{bp}<0.05$ when compared to ondansetron alone $(0.25 \mathrm{mg} / \mathrm{kg}), \mathrm{cp}<0.05$ when compared to ondansetron alone $(0.5 \mathrm{mg} / \mathrm{kg}), \mathrm{dp}<0.05$ when compared to fluoxetine alone. 
In acute study of tail suspension test, ondansetron (0.5 $\mathrm{mg} / \mathrm{kg}$ ), fluoxetine and both combination groups show significant decrease in immobility period as compared to control. Fluoxetine and both combination groups shows significant decrease in immobility compared to ondansetron.

In chronic study of tail suspension test, ondansetron $(0.25$ $\mathrm{mg} / \mathrm{kg}$ ), fluoxetine and both combination groups show significant decrease in immobility period as compared to control. Fluoxetine and both combination groups show significant decrease in immobility compared to ondansetron.
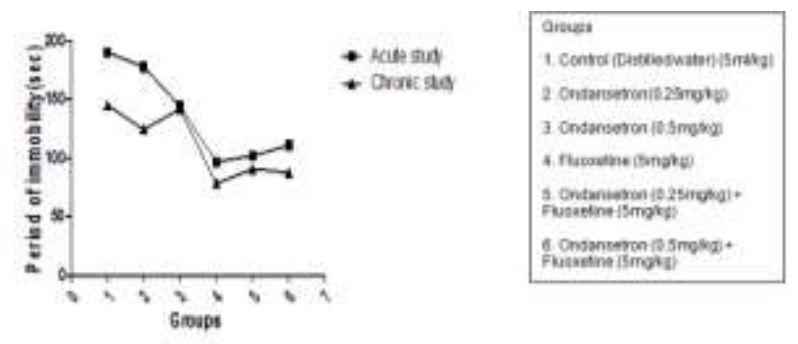

Figure 3: TST (acute and chronic study).

In acute study of open field test there is no significant difference in no. of peripheral squares crossed amongst all groups. In chronic study of Open field test combination of ondansetron $(0.5 \mathrm{mg} / \mathrm{kg})$ and fluoxetine show significant increase in no. of peripheral squares crossed.

In acute study of open field test there is no significant difference in no. of central squares crossed amongst all groups.

In chronic study of open field test, ondansetron (both groups) show significant increase in no. of central squares crossed compared to control. Fluoxetine show significant decrease in no. of central squares crossed compared to control and ondansetron. Combination of ondansetron and fluoxetine in both groups show significant decrease in no. of central squares crossed compared to ondansetron. Combination of ondansetron $(0.25 \mathrm{mg} / \mathrm{kg})$ and fluoxetine show significant increase in no. of central squares crossed compared to fluoxetine.

In acute study of open field test, fluoxetine shows significant increase in total no. of rearing compared to control. Both combination groups shows significant decrease in total no. of rearing compared to fluoxetine.

In chronic study of open field test, ondansetron $(0.5$ $\mathrm{mg} / \mathrm{kg}$ ) significantly increases total no. of rearing compared to control. Fluoxetine and both combination groups show significant decrease in total no. of rearing compared to ondansetron.

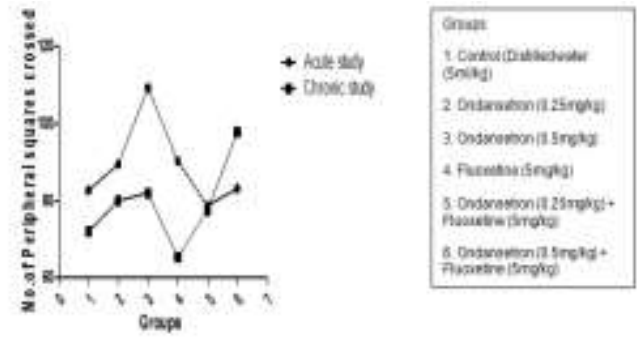

Figure 4: OFT (peripheral squares crossed).

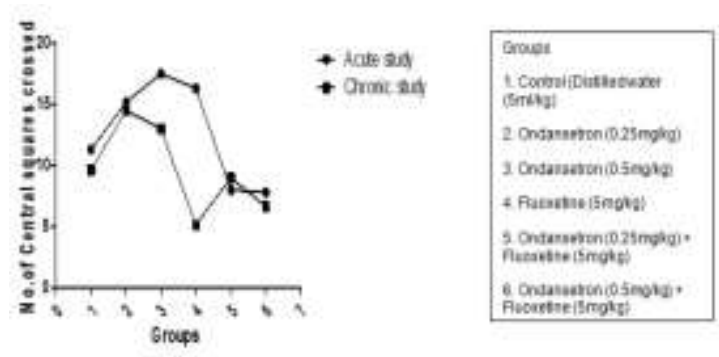

Figure 5: OFT (central squares crossed).
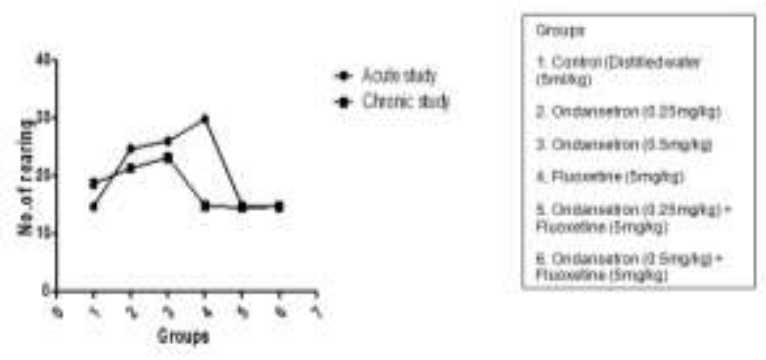

Figure 6: OFT (no. of rearing).

Table 5: Mice brain serotonin estimation.

\begin{tabular}{|llll|}
\hline Group & Drugs & Doses & $\begin{array}{l}\text { Mice brain } \\
\text { serotonin } \\
(\boldsymbol{\mu} / \mathrm{gm}) \\
(\mathbf{M e a n} \pm \text { SEM) }\end{array}$ \\
\hline I & Control(d. $\mathrm{w})$ & $5 \mathrm{ml} / \mathrm{kg}$ & $0.75 \pm 0.08$ \\
\hline II & OND & $0.25 \mathrm{mg} / \mathrm{kg}$ & $0.80 \pm 0.07$ \\
\hline III & OND & $0.5 \mathrm{mg} / \mathrm{kg}$ & $1.04 \pm 0.07$ \\
\hline IV & FLX & $5 \mathrm{mg} / \mathrm{kg}$ & $1.12 \pm 0.08^{\mathrm{a}}$ \\
\hline V & ODN+FLX & $0.25+5 \mathrm{mg} / \mathrm{kg}$ & $1.34 \pm 0.08^{\mathrm{a}, \mathrm{b}}$ \\
\hline VI & ODN+FLX & $0.5+5 \mathrm{mg} / \mathrm{kg}$ & $1.52 \pm 0.08^{\mathrm{a}, \mathrm{b}, \mathrm{c}, \mathrm{d}}$ \\
\hline
\end{tabular}

Statistical analysis of data was carried out by one way ANOVA followed by Tukey's test values expressed as mean \pm SEM [Standard error of mean]; $\mathrm{n}=6$ in each group, $\mathrm{df}=5,30 ;$ ap $<0.05$ when compared to control, bp<0.05 when compared to ondansetron alone $(0.25 \mathrm{mg} / \mathrm{kg}), \mathrm{cp}<0.05$ when compared to ondansetron alone $(0.5 \mathrm{mg} / \mathrm{kg}), \mathrm{dp}<0.05$ when compared to fluoxetine alone.

Mice brain serotonin estimation shows Fluoxetine and combination of ondansetron and Fluoxetine in both groups show significant increase in brain serotonin compared to control. Combination of ondansetron and 
fluoxetine in both groups show significant increase in brain serotonin compared to ondansetron $(0.25 \mathrm{mg} / \mathrm{kg})$. Combination of ondansetron $(0.5 \mathrm{mg} / \mathrm{kg})$ and fluoxetine shows significant increase in brain serotonin compared to ondansetron $(0.5 \mathrm{mg} / \mathrm{kg})$.
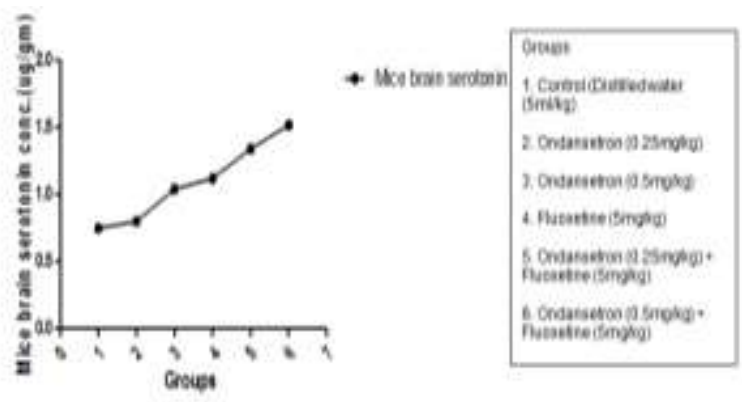

Figure 7: Mice brain serotonin estimation.

\section{DISCUSSION}

Serotonin type-3 $\left(5-\mathrm{HT}_{3}\right)$ receptor antagonists like ondansetron are currently used in the management of nausea and vomiting associated with cancer chemotherapy and radiotherapy. ${ }^{14}$ Interestingly, in the last decade, these molecules have been extensively evaluated for their neuro- psychopharmacological potentials in various pre-clinical and few clinical studies. Several pre-clinical (behavioural, neurochemical and genetic) studies have provided evidences linking $5-\mathrm{HT}_{3}$ receptors and depression. ${ }^{15}$

Therefore, in the present study antidepressant activity of ondansetron was evaluated alone, in comparison and in combination with fluoxetine in Swiss albino mice using all the three models forced swimming test, tail suspension test, and open field test along with its confirmation with brain serotonin estimation to assess antidepressant activity. Tests were done in both acute and chronic models. The duration of immobility was assessed in both FST and TST. Parameters assessed for open field test were no. of square crossed (peripheral and central) and no. of rearing.

In acute and chronic study of FST ondansetron showed significant reduction in duration of immobility as compared to control. The duration of immobility was less in group ondansetron $(0.5 \mathrm{mg} / \mathrm{kg})$ when compared to ondansetron $(0.25 \mathrm{mg} / \mathrm{kg})$ group but it was statistically non-significant $(\mathrm{p}>0.05)$. Both combination groups showed statistically significant antidepressant activity $(\mathrm{p}<0.05)$ as compared to fluoxetine \& ondansetron.

Pre-treatment with OND significantly reduced the duration of immobility in mice indicating antidepressant like effect. It also potentiated the duration of immobility produced by fluoxetine. Also chronic study showing higher significant reduction in immobility as compared to acute FST suggest time taken by ondansetron to build the neurotransmitters as like classical antidepressants.

In acute and chronic study of TST, ondansetron showed significant $(\mathrm{p}<0.05)$ antidepressant effect as compared to control group. Amongst ondansetron only groups, there was no statistically significant difference in the antidepressant activity.

Agents acting via serotonergic pathway can be screened by using this method. This suggests possible mechanism of action of OND in depression. Also combination groups showed higher significant antidepressant activity as compared to ondansetron alone but not as compared to FLX, both acute and chronic test and this may be false negative. False negative results do come in animal studies as shown by Shoeb A et al in antidepressant activity of vanillin in mice. ${ }^{16}$

The result of the open field test in chronic study showed ondansetron $(0.25 \mathrm{mg} / \mathrm{kg}$ and $0.5 \mathrm{mg} / \mathrm{kg})$ increases number of central squares crossed as compared to control which is statistically significant $(\mathrm{p}<0.05)$. The combination group (OND $0.25 \mathrm{mg} / \mathrm{kg}+$ FLX $5 \mathrm{mg} / \mathrm{kg}$ ) showed significantly increased $(\mathrm{p}<0.05)$ number of central squares crossed as compared to fluoxetine (5 $\mathrm{mg} / \mathrm{kg}$ ). The combination group (OND $0.5 \mathrm{mg} / \mathrm{kg}+$ FLX $5 \mathrm{mg} / \mathrm{kg})$ showed significantly increased $(\mathrm{p}<0.05)$ number of peripheral squares crossed as compared to fluoxetine $(5 \mathrm{mg} / \mathrm{kg})$ and control group. Ondansetron $(0.5$ $\mathrm{mg} / \mathrm{kg})$ showed statistically significant $(\mathrm{p}<0.05)$ increase in total number of rearing as compared to control but non-significant findings $(\mathrm{p}>0.05)$ for all the group comparisons.

From our findings open field test carried out to show that the antidepressant effect of drug was not related to stimulation of general locomotor activity. As mobility is not uniformly increased in all the parameters of open field test. This may be because in open field test, animals are not subjected to induced depression as like in forced swimming test and tail suspension test.

Antidepressant activity of ondansetron was confirmed by brain serotonin estimation by UV spectrophotometry. ondansetron $(0.25 \mathrm{mg} / \mathrm{kg}$ and $0.5 \mathrm{mg} / \mathrm{kg})$ showed higher brain serotonin level compared to control group which was statistically non-significant ( $p>0.5)$. The combination group (OND $0.5 \mathrm{mg} / \mathrm{kg}+$ FLX $5 \mathrm{mg} / \mathrm{kg}$ ) showed significantly increased $(\mathrm{p}<0.05)$ brain serotonin compared to control, ondansetron $(0.25 \mathrm{mg} / \mathrm{kg}$ and $0.5 \mathrm{mg} / \mathrm{kg})$ and fluoxetine $(5 \mathrm{mg} / \mathrm{kg})$.

Significant result of acute and chronic dose study in forced swimming test and tail suspension test shows that ondansetron has significant antidepressant effect as compared to control group which is confirmed by brain serotonin estimation, suggesting that ondansetron by blocking $5-\mathrm{HT}_{3}$ receptors results into increase in level of brain serotonin. Further confirmation of our results is 
carried out by analyzing different studies using different models as follows.

Martin et al reported the antidepressant effect of ondansetron, in another model (learned helplessness) in rodents. ${ }^{17}$ Srivastava et al, Chivate et al, Ramamoorthy et al studied antidepressant activity of ondansetron, a 5- $\mathrm{HT}_{3}$ antagonist in mice and compared with desipramine, escitalopram, venlafaxine.

It can be inferred from this study that antidepressant activity of ondansetron is again mediated by similar mechanism i.e. 5- $\mathrm{HT}_{3}$ blockade modulating neuronal release of neurotransmitters. It has been shown that 5hydroxytryptaminergic (5-HT) pathways are involved in pathogenesis of depression apart from noradrenergic pathways in the limbic system. The $5-\mathrm{HT}_{3}$ receptor sites are ligand gated ion channels which mediate the release of a number of neurotransmitters. The $5-\mathrm{HT}_{3}$ receptors have been shown to modulate neuronal release of other neurotransmitters and therefore, other possible mechanism of antidepressant action may be increased release of norepinephrine (NE) due to blockade of 5- $\mathrm{HT}_{3}$ receptors as Blandina et al showed that $5-\mathrm{HT}_{3}$ receptor activation inhibited NE release. ${ }^{18}$

Finally, ondansetron, in both doses $(0.25 \mathrm{mg} / \mathrm{kg}$ and 0.5 $\mathrm{mg} / \mathrm{kg}$ ), produces a greater antidepressant action when combined with the standard antidepressant i.e. fluoxetine. This antidepressant action of combination group was far more significant when compared to both ondansetron and fluoxetine given alone.

The enhanced antidepressant effect observed in our study after combination of ondansetron with fluoxetine is probably a result of additive interaction between two drugs, due to increasing synaptic level of neurotransmitters.

So from our study, we propose that ondansetron is a good antidepressant especially when it is used in combination with a standard antidepressant. Since this is an animal study, we need these results along with the other studies to be confirmed in human studies for further establishment of role of ondansetron as antidepressant.

\section{CONCLUSION}

From this study we conclude that ondansetron alone and especially in combination with fluoxetine possesses significant antidepressant activity in animal models of depression. But further clinical studies are needed to establish role of ondansetron in the treatment of depression.

\section{ACKNOWLEDGEMENTS}

Authors would like to thank Dean GMC Latur for allowing to conduct the work and paramedical staff of department of Pharmacology for their support during experiment.

Funding: No funding sources

Conflict of interest: None declared

Ethical approval: The study was approved by the Institutional Ethics Committee

\section{REFERENCES}

1. Thase ME, Howland RH. Biological process in depression: an update and integration In: Beckham EE, Leber WR, editors. Handbook of Depression. $2^{\text {nd }}$ edition. New York: Guilford;1995:213-79.

2. The world health report. Mental health: new understanding new hope. WHO, Geneva. 2001.

3. Madhav SM. Epidemiological study of prevalence of mental disorders in India. Indian $\mathrm{J}$ Comm Med. 2001;26(4):198-200.

4. Yu ZF, Kong LD, Chen Y. Antidepressant activity of aqueous extracts of Curcuma longa in mice. $\mathrm{J}$ Ethnopharmacol. 2002;83(1-2):161-5.

5. Potdar V, Kibile S. Evaluation of antidepressant-like effect of citrus maxima leaves in animal models of depression. Iran J Basic Med Sci. 2011;14(5):47883.

6. Srivastava SK. Letter to the editor-antidepressant activity of ondansetron, a $5 \mathrm{HT}_{3}$ antagonist. Indian $\mathrm{J}$ Pharmacol.1998;30:411-2.

7. Gupta D, Devadoss T, Bhatt SB, Gautam B, jindal A, Pandey D et al. Antidepressant-like activity of a novel serotonin type-3 $\left(5 \mathrm{HT}_{3}\right)$ receptor antagonist in rodent model of depression. Indian $\mathrm{J}$ exp Biol. 2011;49:619-26.

8. Greenshaw AJ. Behavioral pharmacology of $5-\mathrm{HT}_{3}$ receptor antagonists: A critical update on therapeutic potential. Trends Pharmacol Sci.1993;14(7):265-70.

9. Ramamoorthy $\mathrm{R}$, Radhakrishnan $\mathrm{M}$, Borah $\mathrm{M}$. Antidepressant-like effects of serotonin type-3 antagonist, ondansetron: an investigation in behavior -based rodent models. Behav Pharmacol. 2008;19:29-40.

10. Chivate AN, Chivate ND, Wadkar KA, Naikwade Ns. Comparative study of ondansetron with SSRI in some animal models of depression. J Pharm Res. 2012;5(6):2543-7.

11. Sanmukhani J, Anovadiya A, Tripathi CB. Evaluation of antidepressant like activity of curcumin and its combination with fluoxetine and imipramine: an acute and chronic study. Drug Res. 2011;68(5):769-75.

12. Santosh P, Venugopal R, Nilakash A. Antidepressant activity of methanolic extract of Passiflora foetida leaves in mice. Int J Pharm Pharm sci. 2011;3(1):112-5.

13. Udenfriend S, Weissbach H, Clark C. The estimation of 5-Hydroxytryptamine (serotonin) in biological tissues. J.Biol Chem. 1995;215:337-44.

14. Shrivastava SK. Emesis and antiemetics. A Complete Textbook of Medical Pharmacology. $1^{\text {st }}$ 
edition. Sirmour, Himachal Pradesh: Avichal;2012:1236.

15. Mahesh R, Kumar B, Jindal A, Bhatt S, Devadoss T, Pandey D. Antidepressant-like activity of (4phenylpiperazin-1-yl) (quinoxalin-2-yl) methanone (4a), a novel 5- $\mathrm{HT}_{3}$ receptor antagonist: an investigation in behavior-based rodent models of depression. Indian J Pharmacol. 2012;44(5):560-5.

16. Shoeb A, Chowta M, Pallempati G, Rai A, Singh A. Evaluation of antidepressant activity of vanillin in mice. Indian J Pharmacol. 2013;45(2):141-4.

17. Martin P, Gozlan H, Puech AJ. 5- $\mathrm{HT}_{3}$ receptor antagonists reverse helpless behavior in rats. Eur $\mathbf{J}$ Pharmacol. 1992;212(1):73-8.
18. Blandina $\mathrm{P}$, Goldfarb $\mathrm{J}$, Walcott $\mathrm{J}$, Green $\mathrm{J}$ P. Serotonergic modulation of the release of endogenous norepinephrine from rat hypothalamic slices. J Pharmacol Expl Ther. 1991;256(1):341-7.

Cite this article as: Parekar SM, Dharmadhikari SC, Jaju JB, Pawar GR, Solunke R. Evaluation of antidepressant activity of ondansetron alone and in combination with fluoxetine-an experimental study. Int J Basic Clin Pharmacol 2016;5:90-7. 